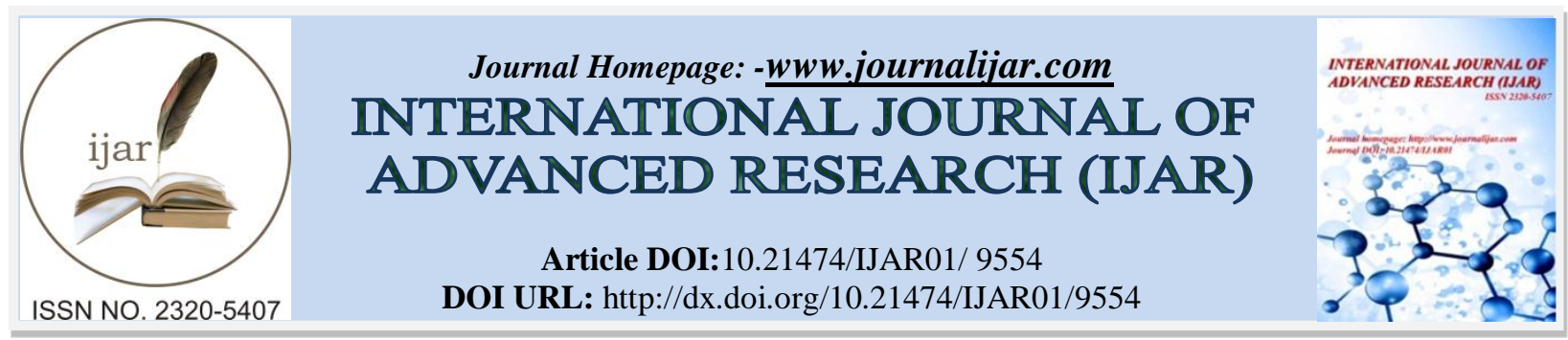

RESEARCH ARTICLE

\title{
STRATEGIC PLANNING ANALYSIS OF SMALL AND MEDIUM ENTERPRISES (SMEs) BORDER AREAS IN INDONESIA.
}

Nanang Suparman ${ }^{1}$ and Mubarok ${ }^{2}$.

Faculty of Social and Political Sciences UIN Sunan Gunung Djati Bandung.

\section{Manuscript Info}

Manuscript History

Received: 08 June 2019

Final Accepted: 10 July 2019

Published: August 2019

Key words:-

Strategical planning, small, medium enterprises.

\begin{abstract}
SMEs already proved to be able to survive from the economic crisis and can sustain the economy of the lower middle society, especially in providing employment, but in the borders area, It has limitation in the development so that the community economy depends heavily on neighboring countries. Thus, SMEs deserve the government's attention to its empowerment. In some regencies and provinces that are directly adjacent to neighboring countries, there are several SMEs where after analysis has been conducted generally has been infiltrate the strategic planning. This research method uses descriptive-analysis with statistical data analysis tools to describe the research variables, especially to see the general overview of responses from respondents. The results showed that the strategic planning of SMEs in the border areas involving the outside constituents desires, the company's people desires, and the company's data base has not received full attention. It is organized informally, this makes comprehensive implementation of strategic planning is not achieved, causing the SMEs to be limited in weak conditions.
\end{abstract}

Copy Right, IJAR, 2019,. All rights reserved.

\section{Introduction:-}

The importance of small and medium enterprises (SMEs) in strengthening the economic structure is evidenced by the growing attention of developed countries to SMEs devolepment. The European Union (UE), even has begun to transform regulation in all its member countries to provide wider space for SMEs after the economic crisis of 1998. Not only developed countries as well as the EU, countries in Asia also started to look at SMEs as an alternative to the economic support, and Indonesia do the same way.

SMEs apparently has the important role. Every economic crisis occurred, the Indonesian government always relies on SMEs as a solution. Thus, SMEs become an important factor for the economic development of Indonesia. However,SMEs still has a several of problems, especially those operates in border area. Governments must strengthen the existence of SMEs in order to ward off the economic crisis in the future. SMEs Strengthening is part of the government's step in accelerating industrialization. Because, small medium industries have been proven to survive amid the economic crisis, can absorb a lot of manpower, and play a strategic role in supporting national food availability in particular. Until 2012, the number of small and medium industrial enterprises recorded in the Ministry of Industry 4 million and absorb 9.4 million people workforce. The investment is generated around Rp 261 trillion with the export value of US $\$ 16.5$ billion or 14.2 percent of the total export of non-oil and gas industries. This 
indicates that the small industry has an important role for the national industry. The obstacles that are often faced by small industries are the limitation of human resources ability both in the technical and managerial sides. There are also technological constraints and weak market and capital access. Amid the declining economic dynamics of Indonesia, such as the current transaction deficit, trade balance deficit, to the weakening of the rupiah currency exchange rate, the SMEs sector in the region could be the support of the national economy. Moreover, for SMEs who can already export. The empowerment of SMEs becomes one of the pillars and backbone of national economy.

Based on the Ministry of Cooperatives, 2013 recorded 56.5 million units of SMEs that absorbed 97 percent of the total labor force of the agricultural sector reached 107 million people. This is because the majority of SMEs are in the agriculture sector. Several years in the future the SMEs sector will be able to survive as the crisis of 1997 and 2008. This was evidenced and contributed by the SMEs sector to the gross domestic product tire growth last year, which reached 57.5 percent. Related to the classical issues of SMES that have been outlined above, suspected problems of the SMEs weakness because of strategic planning that is still not optimal preparation and utilization.

\section{Library Overview:-}

Based on what was stated by Allison and Kaye (2005:56), strategic planning is a systematic process that is agreed upon by the organization and builds involvement among the major stakeholders on the essential priorities for its mission and responsiveness to the operating environment. Strategic planning is primarily used to sharpen the organization's focus, so that all organizational resources are used optimally to serve the organization's mission. This means that strategic planning to guide an organization should be responsive to a dynamic, difficult-to-do environment.

The strategic planning process consists of three main components (Armstrong, 1982 in Shrader et al., 1989:54) namely: (1) The formulation, which includes mission development, main goal determination, external and internal environmental assessment and evaluation and Alternative elections; (2) Application; and (3) control. Orpen (1985:98) stated that strategic planning benefits small companies by encouraging them to find new alternatives to increase their sales and competitive positions. According to Bracket et al. (1988:76) suggests that mature strategic planning benefits small companies in a rapidly growing dynamic industry.

Based on the results of the study of Rue and Ibrahim (1998:44) and Shrader et al. (1989:59), stating that managers in small and medium enterprises indicated that the company's plans were generally undertaken on their own, meaning managers and planners. Strategic planning on various business conditions that are supposed to be the company's well-large or small. Because with strategic management will be able to serve as a means to communicate the objectives of the company as well as alternative roads that will be taken to achieve these objectives.

Strategic planning usually covers a period of one to five years (Rue and Ibrahim, 1998:51). So it can be concluded that strategic planning becomes a guideline for an organization to respond to a dynamic and difficult-to-do environment. Strategic planning emphasizes the importance of making decisions that place organizations to successfully respond to environmental changes. In an effort to improve competitive advantage, it is worth studying more about the factors that can affect a sitategis planning so as to create the value of competitive advantage.

On the basis of strategic planning, then there are 2 (two) basic strategic planning companies, namely: first, the intuitive planning of the anticipatory is a planning based on experiences, instincts, considerations and reflective A manager, in other words the intuitive strategic planning of anticipatory is planning based on past experiences, considerations and a reflective way of thinking. Usually such planning is determined not formally alias non-formal; And second is the formal long-term planning of planning based on procedures, research, involving many people and generating a set of written plans. So, this kind of planning can be said to be a formal strategic planning (written) (Robinson and Pearce, 1983:55)

Strategic planning has elements that form it. Below are the elements depicted through strategic planning models according to Steiner (1997:123), namely: Expectation from outside constituents, the database, expectations from people inside the company, and identification of opportunities, Rosudgeon strengths and weaknesses (SWOT). This strategic planning Model according to Steiner, is a strategic planning that can be applied also to SMEs. However, the strategic planning element regarding the SWOT identification is not used in the study because every company is assumed to never escape the analysis of the SWOT's company while drafting strategic planning. Thus, the most important involves the expectations of internal and external parties beside the company data. 
As for the identification of SMEs as locus This research, it has many definitions regarding SMEs. Each country has its own definition for SMEs. However, in Indonesia, SMEs according to Law No 20 year 2008 divided into two senses, namely: Small business is an entity that has net worth more than Rp 50,000,000.00 (fifty million rupiah) up to at most Rp 500,000,000.00 (five hundred million Rupiah) does not include land and business premises, and has annual sales results of more than $\mathrm{Rp} 300,000,000.00$ (three hundred million rupiah) up to at most $\mathrm{Rp}$ 2,500,000,000.00 (two billion five hundred million rupiahs). Meanwhile, medium Enterprises is a business entity that has a net worth more than $\quad \mathrm{Rp} \mathrm{500,000,000.00} \mathrm{(five} \mathrm{hundred} \mathrm{million} \mathrm{rupiah)} \mathrm{up} \mathrm{to} \mathrm{at} \mathrm{most} \mathrm{Rp}$ $10,000,000,000.00$ (ten billion rupiah) excluding land and business premises, as well as Has annual sales of more than Rp 2,500,000,000.00 (two billion five hundred million rupiah) up to at most Rp 50,000,000,000.00 (fifty billion rupiah).

\section{Research Methods:-}

This research uses descriptive analysis. A descriptive analysis in this study uses quantitative data with statistical data analysis (SDA). The analysis of descriptive data is used in this study to describe the data in the research variables, especially to see the general overview of the respondents ' responses.

The steps taken for this descriptive analysis are as follows:

1. Each indicator by the respondent is classified in five alternate answers. The answer rating of each indicator is rated between 1 and 5 .

2. To display the respondent's response is used descriptive statistics such as frequency distribution and displayed in the form of tables.

3. To answer a description of the variables/dimensions this study used the criteria of valuation Category: Very high, high, enough, low and very low. With the following provisions and calculations:Skor minimum (\%)

$\begin{array}{lllr}=1 / 5 \times 100 & = & 20 \% \\ -\quad \text { Maximum Score }(\%) & =5 / 5 \times 100 & = & 100 \% \\ -\quad \text { Range }(\%) & =100 \%-20 \% & = & 80 \% \\ -\quad \text { Interval }(\%) & =80 \%: 5 & = & 16 \%\end{array}$

So that the interval class calculation obtained the following catagorization:

Table 1:-Respondents answer score Catagorization

\begin{tabular}{|l|c|l|}
\hline No & Total score Interval & Category Valuation \\
\hline 1 & $20 \%-35,99 \%$ & Very Low \\
\hline 2 & $36 \%-51,99 \%$ & Low \\
\hline 3 & $52 \%-67,99 \%$ & Enough \\
\hline 4 & $68 \%-83,99 \%$ & High \\
\hline 5 & $84 \%-100 \%$ & Very High \\
\hline
\end{tabular}

Source: Research Results, 2013

Tabel 2:-Operationalization of strategic Research object planning

\begin{tabular}{|c|c|c|c|}
\hline Object & Dimension & \multicolumn{2}{|c|}{ Indicator } \\
\hline \multirow{13}{*}{$\begin{array}{l}\text { Strategic } \\
\text { Planning }\end{array}$} & \multirow[t]{6}{*}{ The desire of outer constituents } & 1 & Community \\
\hline & & 2 & Community (certain) \\
\hline & & 3 & Capital Owner \\
\hline & & 4 & Customer \\
\hline & & 5 & Supplier \\
\hline & & 6 & Creditor \\
\hline & \multirow[t]{4}{*}{ People in company desires } & 1 & $\mathrm{CEO}$ \\
\hline & & 2 & Low Level Manager \\
\hline & & 3 & Worker Production Process \\
\hline & & 4 & Administrative Staff \\
\hline & \multirow[t]{3}{*}{ Company Base Data } & 1 & Past Performance \\
\hline & & 2 & Current situation \\
\hline & & 3 & Future Forecasting \\
\hline
\end{tabular}

Source: Research Results, 2013 


\section{Research Result And Discussion:-}

Strategic planning is one of the most important factors for the success of a company. Companies that do not have strategic planning, like a person who does not have a living view that will lead to a purpose. Therefore, strategic planning is absolutely necessary to direct the company's activities to arrive at one goal. Thus, without strategic planning, a company will not reach a goal because it does not know what the company is established.

Strategic planning whether formal or non-formal is indispensable for a company both large and small and medium scale. Even according to some strategist, small and medium scale companies need strategic planning rather than large companies. Because of a small or medium-sized business, if you want to enter into a large scale category, it requires a plan that is mature in running its business wheels and should be arranged more seriously. While the company is large scale, with the experience of success, strategic planning is always there and ordinary things. Thus, for small and medium enterprises, strategic planning is essential to create and enhance competitive advantage so as to grow and enlarge the company's body. As for large companies, strategic planning is nothing more to maintain its business stability.

In order to make it easier to know the research results of the strategic planning of small and medium enterprises in this frontier district, researchers have conducted analysis of each dimension. These dimensions are: the desires of the outer constituents, the wishes of the company's people and the company Data Base.

\section{Outer constituents Desire Dimensions}

Related to the dimensions of the outside constituent desire, then submitted 6 (six) questions regarding the subject as follows: strategic planning formulation Consider the wishes of the community, strategic planning formulation consider the desire Specific community related, strategic planning formulation to consider the wishes of the capital owners/investors, strategic planning formulation consider the wishes of customers, strategic planning formulation consider Suppliers ' desires, and strategic planning arrangements consider the wishes of creditors/reticing funds. And to find out about the respondent's response to the question items, it can be seen in the table below:

Table 3:-Respondents' response to dimensions

The desire of outer constituents

\begin{tabular}{|c|c|c|c|c|c|c|c|c|c|c|c|c|}
\hline \multirow[t]{3}{*}{ Item } & \multicolumn{10}{|c|}{ Alternative Answer } & \multirow{2}{*}{\multicolumn{2}{|c|}{ Total Score }} \\
\hline & \multicolumn{2}{|c|}{5} & \multicolumn{2}{|l|}{4} & \multicolumn{2}{|l|}{3} & \multicolumn{2}{|l|}{2} & \multicolumn{2}{|c|}{1} & & \\
\hline & $\mathbf{F}$ & $\%$ & $\mathbf{F}$ & $\%$ & $\mathbf{F}$ & $\%$ & $\mathbf{F}$ & $\%$ & $\mathbf{F}$ & $\%$ & Score & $\%$ \\
\hline 1 & 66 & 56.41 & 50 & 42.74 & 1 & 0.65 & 0 & 0.00 & 0 & 0.00 & 533 & 91.11 \\
\hline 2 & 55 & 47.01 & 55 & 47.01 & 5 & 4.27 & 1 & 0.85 & 1 & 0.85 & 513 & 87.69 \\
\hline 3 & 64 & 54.70 & 51 & 43.59 & 1 & 0.85 & 1 & 0.85 & 0 & 0.00 & 529 & 90.43 \\
\hline 4 & 44 & 37.61 & 0 & 59.83 & 3 & 2.56 & 0 & 0.00 & 0 & 0.00 & 509 & 87.01 \\
\hline 5 & 40 & 34.19 & 69 & 58.97 & 3 & 2.56 & 3 & 2.56 & 2 & 1.7 & 493 & 84.27 \\
\hline 6 & 42 & 35.90 & 63 & 53.85 & 9 & 7.69 & 2 & 1.71 & 1 & 0.85 & 494 & 84.44 \\
\hline Total & 311 & 44.30 & 358 & 51.00 & 22 & 3.13 & 7 & 1.00 & 4 & 0.57 & 3071 & 87.49 \\
\hline
\end{tabular}

Source: Research Results, 2014

By looking at the total percentage score in the table above and related to the assessment categorisation as stated in the table above, it can be explained that the cumulative score is $87.49 \%$, which means that the desire dimension The outer constituents are in a "very high" category.

\section{Dimensions of people in company desires}

Related to the dimensions of people's wishes in the company, then asked 4 (four) questions regarding the subject as follows: strategic planning formulation Consider the wishes of the company leadership, strategic planning formulation consider Head of section, Strategic planning drafting considers the wishes of the related workers directly production, and strategic planning drafting considers the wishes of administrative employees. And to find out about the respondent's response to the question items, maim can be seen in the table below:

Table 4:-Respondents' response to dimensions People in company desires

\begin{tabular}{|l|l|l|l|l|l|}
\hline \multirow{2}{*}{ Item } & \multicolumn{4}{|l|}{ Alternative Answer } & Total Score \\
\cline { 2 - 5 } & $\mathbf{5}$ & $\mathbf{4}$ & $\mathbf{3}$ & $\mathbf{1}$ & \\
\hline
\end{tabular}




\begin{tabular}{|l|l|l|l|l|l|l|l|l|l|l|l|l|}
\hline & $\mathbf{F}$ & $\mathbf{\%}$ & $\mathbf{F}$ & $\mathbf{\%}$ & $\mathbf{F}$ & $\mathbf{\%}$ & $\mathbf{F}$ & $\mathbf{\%}$ & $\mathbf{F}$ & $\mathbf{\%}$ & Score & \% \\
\hline 1 & 50 & 42.74 & 60 & 51.28 & 5 & 4.27 & 2 & 1.71 & 0 & 0.00 & 509 & 87.01 \\
\hline 2 & 42 & 35.90 & 67 & 57.26 & 7 & 3.98 & 1 & 0.85 & 0 & 0.00 & 501 & 85.64 \\
\hline 3 & 47 & 40.17 & 66 & 56.41 & 2 & 1.71 & 2 & 1.71 & 0 & 0.00 & 509 & 87.01 \\
\hline 4 & 40 & 34.19 & 67 & 57.26 & 9 & 7.69 & 1 & 0.85 & 0 & 0.00 & 497 & 84.96 \\
\hline Total & $\mathbf{1 7 9}$ & 38.25 & $\mathbf{2 6 0}$ & 55.36 & $\mathbf{2 3}$ & 4.91 & $\mathbf{6}$ & 1.28 & $\mathbf{0}$ & 0.00 & $\mathbf{2 0 1 6}$ & 86.15 \\
\hline
\end{tabular}

Source: Research Results, 2014

By looking at the total percentage score in the table above and related to the assessment categorisation as stated in the table above, it can be explained that the cumulative score is $86.15 \%$, which means that the desire dimension People in the company are in a "very high" category.

\section{Enterprise Data Base Dimensions}

Related to the company's Base Data dimension, there are 3 (three) questions regarding the following subject: Strategic planning formulation considering past performance, strategic planning formulation considering the current situation, and Strategic planning to consider the approximate situation in the future. And to find out about the respondent's response to the question items, it can be seen in the table below:

Tabel 5:-Respondents' response to company Base Data Dimensions

\begin{tabular}{|c|c|c|c|c|c|c|c|c|c|c|c|c|}
\hline \multirow[t]{3}{*}{ Item } & \multicolumn{10}{|c|}{ Alternative Answer } & \multirow{2}{*}{\multicolumn{2}{|c|}{ Total Score }} \\
\hline & \multicolumn{2}{|c|}{5} & \multicolumn{2}{|l|}{4} & \multicolumn{2}{|l|}{3} & \multicolumn{2}{|l|}{2} & \multicolumn{2}{|c|}{1} & & \\
\hline & $\mathbf{F}$ & $\%$ & $\mathbf{F}$ & $\%$ & $\mathbf{F}$ & $\%$ & $\mathbf{F}$ & $\%$ & $\mathbf{F}$ & $\%$ & Score & $\%$ \\
\hline 1 & 59 & 50.43 & 54 & 46.15 & 3 & 2.56 & 1 & 0.85 & 0 & 0.00 & 522 & 89.23 \\
\hline 2 & 42 & 35.90 & 64 & 54.70 & 9 & 7.69 & 2 & 1.71 & 0 & 0.00 & 497 & 84.96 \\
\hline 3 & 45 & 38.46 & 68 & 58.12 & 4 & 3.42 & 0 & 0.00 & 0 & 0.00 & 509 & 87.01 \\
\hline Total & 146 & 41.60 & 186 & 52.99 & 16 & 4.56 & 3 & 0.85 & 0 & 0.00 & 1528 & 87.07 \\
\hline
\end{tabular}

Source: Research Results, 2014

By looking at the total percentage of score in the table above and related to the assessment categorisation as stated above, it can be explained that the cumulative score is $87.07 \%$, which means the dimension Data Base The company is in a "very high" category.

In order to know the respondents ' answers to all dimensions of strategic planning, you can see the following table:

Tabel 6:-Respondents' response to strategic planning

\begin{tabular}{|c|c|c|c|c|c|c|c|c|c|c|c|c|}
\hline \multirow[t]{3}{*}{ Item } & \multicolumn{10}{|c|}{ Alternative Answer } & \multirow{2}{*}{\multicolumn{2}{|c|}{ Total Score }} \\
\hline & \multicolumn{2}{|c|}{5} & \multicolumn{2}{|l|}{4} & \multicolumn{2}{|l|}{3} & \multicolumn{2}{|l|}{2} & \multicolumn{2}{|l|}{1} & & \\
\hline & $\mathbf{F}$ & $\%$ & $\mathbf{F}$ & $\%$ & $\mathbf{F}$ & $\%$ & $\mathbf{F}$ & $\%$ & $\mathbf{F}$ & $\%$ & Scor & $\%$ \\
\hline $\mathrm{X} 1$ & 311 & 44.30 & 358 & 51.00 & 22 & 3.13 & 7 & 1.00 & 4 & 0.57 & 3071 & 87.49 \\
\hline $\mathrm{X} 2$ & 179 & 38.25 & 260 & 55.56 & 23 & 4.91 & 6 & 1.28 & 0 & 0.00 & 2016 & 86.15 \\
\hline X3 & 146 & 41.60 & 186 & 52.99 & 16 & 4.56 & 3 & 0.85 & 0 & 0.00 & 1528 & 87.07 \\
\hline Total & 636 & 41.81 & 804 & 52.86 & 61 & 4.01 & 16 & 1.05 & 4 & 0.26 & 6615 & 86.90 \\
\hline
\end{tabular}

Source: Research Results, 2014

It can be explained that the cumulative score is $86.90 \%$, which means that strategic planning is in a "very high" category. But from 3 (three) dimensions above, there are dimensions that need to get an increase in attention, namely the dimension of constituent desire in the company so that it can contribute to the improvement of SME performance in the future.

Based on the table above, strategic planning that has been conducted by SMES has involved all three elements of the desire of outer constituents, the wishes of people in the company and the company Database, but the implementation of strategic planning that has been made has not been done optimally. Strategic planning that has been made by UKM also turned out that many are arranged informally (not specifically written), thus making the implementation of strategic planning is not implemented perfectly. 


\section{Conclusion and Suggestions:- \\ Conclusion:-}

From the results of the study revealed that of the three dimensions that have been tested, giving the idea that both the dimensions of the desire of outer constituents, the wishes of people in the company and the company Database shows that it is valid Research into SME strategic planning. That is, an SME will not achieve its performance when in drafting its strategic planning does not involve the three dimensions. If one of the dimensions is eliminated in strategic planning, then the strategic planning will not be perfect and will not help the SME to achieve its best performance. Thus, the so-called strategic planning is the one that involves the above three things. Not to be said strategic planning but rather integrating three things in the form of outer constituents desire, the wishes of the company's people and company Database. Regarding the weakness of SMES in Indonesia, this is due to several factors, including the implementation that is less optimal by SMES in implementing strategic planning that has been compiled.

\section{Suggestions:-}

Therefore it is advisable, SMES must always implement its strategic planning optimally, and the strategic planning should be used as a benchmark in conducting operational activities of the company. In addition, SMES are advised to make their strategic plan formally, which is done in writing as a special document. With this special and unique document, strategic planning is expected to be implemented perfectly.

\section{References:-}

1. Allison, Kaye. 2005. Perencanaan Strategis Bagi Organisasi Nirlaba. Jakarta: Yayasan Obor Indonesia.

2. Shrader, C.B, and Mulford, CI, and Blackburn, V.L. 1989. "Strategic and Operational Planning Uncertainty, and Performance In Small Firms”. Journal of Small Business Management (October): pp.45-60.

3. Hillary, Ruth. (2000). Small and Medium-Sized Enterprises and the Environment. Routledge.

4. Humprey, Nicholas. (2010). Small Business Guide. Penguin.

5. Lohana, Sarika. (2014). Micro, Small, and Medium Enterprises (MMSME's) for Inclusive Growth. New Century Publications.

6. Orpen, C. 1985. "The Effects Of Need For Achievement And Need For Independence On The Relationship Between Perceived Job Attributes And Managerial Satisfaction And Performance". International Journal of Psychology 20(2): 207-219.

7. North, Klaus. (2016). Competitive Strategies for Small and Medium Enterprises. Springer International Publishing

8. Bracker, J.S. and Keats, B.W. and Pearson, J.N. 1988. "Planning And Financial Performance Among Small Firms In A Growth Industry". Strategic Management Journal Vol. 9: pp. 591-603.

9. Rue, LW, and Ibrahim, N..A. 1998. "The Relationship between Planning Sophistication and Performance in Small Businesses". Journal of Small Business Management (October): pp.24-32.

10. Robinson, R. B., \& Pearce, J. A. 1983. "The impact of formalized strategic planning on financial performance in small organizations". Strategic Management Journal 4(July-September), 197-207.

11. Steiner, G. A. 1997. "Strategic Planning: What Every Manager Must Know". New York: The Free Press Publishing.

12. Suparman, N,. Candra D., \& Sari, A. (2019). Bureucratic Behavior in the Implementation of Capital Expenditure Budget in the Office of Public Work and Spatial Planning of Sumedang Regency . Jurnal Bina Praja: Journal of Home Affairs Governance, 11(1) , 99-109. https://doi.org/10.21787/jbp.11.2019.99-109.

13. Suparman, N.,Sakti, F.T.\& Engkus. (2018). Evaluasi Program KB pada Era Desentralisasi di Kuningan Jawa Barat. JPPUMA: Jurnal Ilmu Pemerintahan dan Sosial politik UMA (Journal of Governance and Political Social UMA), 6(2): 122-131. 